\title{
Arsenic and Mercury Mobility in Brazilian Sediments from the São Francisco River Basin
}

\author{
Patrícia S. Rezende, Priscila A. S. Moura, Walter A. Durão Jr., Clésia C. Nascentes, \\ Cláudia C. Windmöller and Letícia M. Costa*
}

\author{
Departamento de Química, ICEx, Universidade Federal de Minas Gerais, \\ Av. Presidente Antônio Carlos, 6627, 31270-901 Belo Horizonte-MG, Brazil
}

\begin{abstract}
Os sedimentos possuem propriedades de acumulação de poluentes e a determinação de elementos tóxicos nessas amostras permite avaliar o seu ciclo geoquímico. Arsênio e mercúrio foram determinados em 28 amostras de sedimento da Bacia do Rio São Francisco, Minas Gerais, Brasil, por geração de hidretos acoplada à espectrometria de absorção atômica (HG AAS). Foram empregados procedimentos de digestão pseudo-total empregando $\mathrm{HCl}: \mathrm{HNO}_{3}(3: 1 \mathrm{v} / \mathrm{v})$ e extração parcial com $\mathrm{HCl} 1 \mathrm{~mol} \mathrm{~L}^{-1}$. Realizou-se ainda a determinação de $\mathrm{Hg}$ nas amostras sólidas, utilizando-se um analisador direto de mercúrio. Observou-se que $46 \%$ das amostras apresentaram concentrações de As acima do limite de nível 1 estabelecido pela Resolução 344/2004 do CONAMA e que $14 \%$ excederam o limite de nível 1 para $\mathrm{Hg}$. As amostras com altas concentrações de $\mathrm{Hg}$ foram também analisadas por termodessorção acoplada à espectrometria de absorção atômica (TDAAS) para especiação e os termogramas apontaram somente a presença da espécie $\mathrm{Hg}$ (II).
\end{abstract}

\begin{abstract}
Sediments have metal accumulation properties, then, an evaluation of their geochemistry cycle is feasible via toxic element determination of these samples. Arsenic and mercury determinations were accomplished in 28 sediment samples from the São Francisco River Basin, Minas Gerais, Brazil. For sample pretreatment were employed a pseudo-total digestion procedure with $\mathrm{HCl}: \mathrm{HNO}_{3}$ $(3: 1 \mathrm{v} / \mathrm{v})$ and a partial extraction procedure with $1 \mathrm{~mol} \mathrm{~L}^{-1} \mathrm{HCl}$. Arsenic and mercury were analysed by hydride generator atomic absorption spectrometry (HG AAS). Mercury determination was realized in the solid samples by direct mercury analyzer (DMA). It was observed that $46 \%$ of the samples presented arsenic concentrations above Brazil's legal limits, and 14\% of samples exceeded the established mercury limit. The samples with high mercury content were also analysed by thermodesorption coupled to atomic absorption spectrometry (TDAAS) and only $\mathrm{Hg}$ (II) was identified.
\end{abstract}

Keywords: arsenic, mercury, sediment samples, environmental monitoring, São Francisco River

\section{Introduction}

In most aquatic environments, dissolved metal concentrations in overlying water are low due to the precipitation of solids or the adsorption of suspended particles and the deposition of these particles as sediments. ${ }^{1}$

Sediment is a matrix comprising inorganic and organic particles. It is relatively heterogeneous in terms of its physical, chemical, and biological characteristics. Sediments have an important role in the transport and storage of contaminants, being of high relevance in the identification of contaminant sources and in the determination of dispersion pathways. Sediment quality determines the biodiversity and the ecological health in

*e-mail: leticia@qui.ufmg.br aquatic systems as well as being economically important in the environmental assessment of coastal areas. ${ }^{2}$

São Francisco is the third largest hydrographic basin in Brazil. It is responsible for drainage of a $640.000 \mathrm{~km}^{2}$ area, corresponding to $8 \%$ of land in the country of Brazil. About $40 \%$ of the basin is located in the state of Minas Gerais and it is divided in four regions: High São Francisco (where its source is located), Middle São Francisco, Sub Middle São Francisco, and Low São Francisco, which ends in the Atlantic Ocean. ${ }^{3}$ According to $\mathrm{IBGE}^{4}$ (Instituto Brasileiro de Geografia e Estatística) in the 2000 demographic census, the total population around the basin was about 13 million. This basin has great social-economic importance to Brazil, including agricultural irrigation, river transportation (in some areas), production of hydroelectric energy, tourism and leisure. 
Anthropogenic activities, mainly the progressive implantation of economic activities and uncontrolled population growth, are responsible for serious pollution problems, which can cause negative effects in the hydrologic regime, especially concerning to water quality and quantity. A crucial aspect of the degradation of the São Francisco Basin is the introduction of metals, which occurs via mining activities, the use of fertilizers, and the release of domestic and industrial effluents often without any pretreatment. ${ }^{3,5}$

In aquatic systems, metals are distributed as colloids, species which are water soluble, and as materials in suspension and in sediments. Sediments have high capacity for adsorbing and retaining contaminants. Metal concentrations in sediments and in river waters can be easily altered by deposition and remobilization processes. It is estimated that less than $1 \%$ of these pollutants are water soluble, so most are stored in sediments. ${ }^{6}$

Arsenic and mercury are recognizable toxic elements, which can cause serious damages to the biota. ${ }^{7}$ The presence of $\mathrm{Hg}$ as a pollutant comes from the use of its amalgamation property to increase efficiency of gold extraction. In Minas Gerais, mining began at the end of the $17^{\text {th }}$ century although this practice has been in decline recently due to actions by environmental inspection organizations. It is estimated that gold exploration represents almost 70\% of $\mathrm{Hg}$ released by anthropogenic sources in Brazil. ${ }^{8}$ Other anthropogenic contribution occurs through prospecting, the electrolytic production of chlorine-soda, and the use of fossil fuels, waste incinerators, pigments, pesticides, mercury vapor lamps, batteries, and dental products. ${ }^{9}$

All $\mathrm{Hg}$ compounds have high toxicity indexes concerning living organisms with organic $\mathrm{Hg}$ species being the most toxic. ${ }^{10}$ Mercury occurs naturally with other elements, mainly sulfur, forming the cinnabar mineral $(\mathrm{HgS})$. Other natural $\mathrm{Hg}$ sources are volcanic eruptions, natural evaporation, and $\mathrm{Hg}$ mines. ${ }^{9}$

Mercury determination in sediments is a useful tool to evaluate the impact in the aquatic environment. In some studies, ${ }^{8,11-15} \mathrm{Hg}$ determination in sediment samples showed levels above of those allowed by the Brazilian legislation $\left(0.17 \mu \mathrm{g} \mathrm{g}^{-1}\right)$, according to level 1 from 2004 CONAMA Resolution 344 (Conselho Nacional do Meio Ambiente). ${ }^{16}$ Windmöller et al., ${ }^{8}$ between October 2002 and March 2003, studied sediment samples from the Iron Quadrangle area, obtaining values for $\mathrm{Hg}$ concentrations between 0.05 and $1.10 \mu \mathrm{g} \mathrm{g}{ }^{-1}$. Mozeto et al. ${ }^{15}$ obtained $\mathrm{Hg}$ concentrations up to $2.5 \mu \mathrm{g} \mathrm{g}^{-1}$ between June 2005 and January 2006 in the Três Marias Dam area.

High As levels in soil, sediment, and water can also be observed near gold exploration areas where the mineralogical occurrence of both metals is correlated. ${ }^{17}$ Arsenic can be introduced to the environment by natural and anthropogenic sources. The main anthropogenic sources include mining activities, glass and pesticide manufacturing, and the use of leather and wood preservatives. Two main natural As sources are volatilization and volcanic activity, responsible for almost half of the total As released. ${ }^{18}$ Arsenic is often associated with minerals, especially $\mathrm{Au}$, as arsenopyrite. Arsenic toxicity is related to the chemical species it forms, inorganic species are the most toxic. ${ }^{18}$ Arsenic monitoring in sediments have been studied for decades. ${ }^{18-21}$ Borba et al. ${ }^{20}$ accomplished As measurements between 1997 and 1998 in Iron Quadrangle area and obtained concentrations higher than $1000 \mu \mathrm{g} \mathrm{g}^{-1}$ in sediments from the Velhas River. Deschamps et al. ${ }^{18,21}$ studied the same area and found values up to $3300 \mu \mathrm{g} \mathrm{g}^{-1}$ between 1998 and 2003. According to CONAMA, ${ }^{16}$ the legal limit of As at level 1 is $5.9 \mu \mathrm{g} \mathrm{g}^{-1}$.

In this work, the determination of $\mathrm{As}$ and $\mathrm{Hg}$ was realized in sediments from the High and Middle courses of the São Francisco River Basin. Sediment samples were submitted to sample preparation via aqua regia pseudo-total digestion and $1.0 \mathrm{~mol} \mathrm{~L}^{-1} \mathrm{HCl}$ partial extraction procedures. Arsenic and mercury determination were carried out in a hydride generator atomic absorption spectrometry (HG AAS). Total mercury and $\mathrm{Hg}$ oxidation state were determined in a solid sample by direct mercury analyzer (DMA) and by thermodesorption coupled to atomic absorption spectrometry (TDAAS), respectively.

\section{Experimental}

\section{Samples and reagents}

Sediment samples were collected in 28 points from the São Francisco River Basin (Figure 1) as described in Table 1. Sampling points were distributed as follows: seven in the Paraopeba River sub-basin, three in the Velhas River sub-basin, one in the Verde Grande River sub-basin, twelve in the Paracatu River sub-basin, one in the Abaeté River, and four in the São Francisco River, being one in the High São Francisco and three in the Middle São Francisco. Samples were collected from September 4, 2007, to August 28, 2008.

Posterior sample collection was made at PTE 023 location. This sampling was done with an auger in three different depth intervals $(0-30,3-60$, and 6-90 cm). Furthermore, three other samples from the same area were collected, one from each margin and the third one from the middle of the water flow.

Sediments samples were stored in plastic flasks under refrigeration until handled in lab. They were dried at 


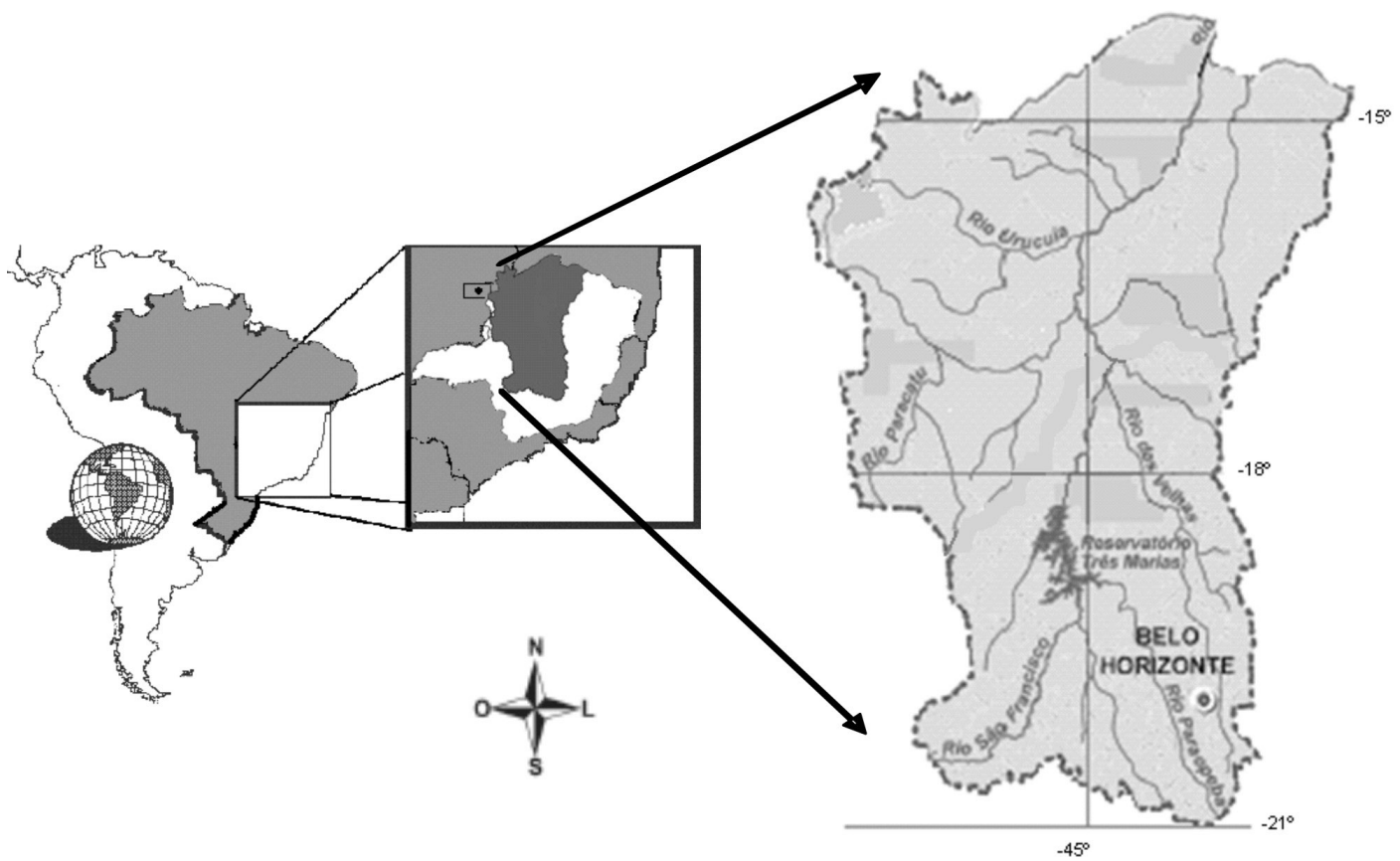

Figure 1. The São Francisco River Basin from Minas Gerais State.

Table 1. Sampling points and principal pollutant sources

\begin{tabular}{|c|c|c|c|}
\hline Sub-basins & Rivers & Sampling points & Principal Pollutant Sources \\
\hline \multirow{8}{*}{ Paracatu } & Córrego Rico & PTE 023 & \multirow{8}{*}{$\begin{array}{l}\text { Agriculture; Extraction of jewel, sand, clay and } \\
\text { limestone; Domestic sewage; Gold mining and } \\
\text { clandestine prospecting; Mining activities effluents }\end{array}$} \\
\hline & Paracatu & PTE 007, PTE 033 & \\
\hline & Ribeirão Entre Ribeiros & PTE 031 & \\
\hline & Ribeirão Escurinho & PTE 013 & \\
\hline & Ribeirão São Pedro & PTE 025, PTE 029 & \\
\hline & Escuro & PTE 015 & \\
\hline & Preto & PTE 027, PT 007 & \\
\hline & Santa Catarina & PTE 003, PTE 005 & \\
\hline \multirow{3}{*}{ Paraopeba } & Maranhão & BP 084 & \multirow{3}{*}{$\begin{array}{l}\text { Food and steel industries; Extraction of slate, sand, } \\
\text { clay and kaolin; Extraction of iron and manganese; } \\
\text { Domestic sewage }\end{array}$} \\
\hline & Paraopeba & ВР 029, ВР 036, ВР 068, ВР 070, ВР 079 & \\
\hline & Sarzedo & BP 086 & \\
\hline \multirow[b]{2}{*}{ São Francisco Norte } & Abaeté & SF 017 & \multirow{2}{*}{$\begin{array}{l}\text { Agriculture; Cattle; Swine culture; Metallurgical } \\
\text { activities; Extraction of limestone and manganese } \\
\text { minerals; Food industries; Domestic sewage; Mining } \\
\text { activities effluents }\end{array}$} \\
\hline & São Francisco & SF 015, SF 019, SF 027, SF 033 & \\
\hline Velhas & Velhas & BV 142, BV 149, BV 156 & $\begin{array}{l}\text { Agriculture; Aviculture; Cattle; Gold mining; Swine } \\
\text { culture; Domestic sewage and urban expansion; } \\
\text { Industrial effluents }\end{array}$ \\
\hline Verde Grande & Verde Grande & VG 005 & $\begin{array}{l}\text { Food, metallurgical and textile industries; Domestic } \\
\text { sewage }\end{array}$ \\
\hline
\end{tabular}

room temperature, manually desagregated and sieved into three different categories $(<0.063 \mathrm{~mm}, 0.063-2 \mathrm{~mm}$, and $>2 \mathrm{~mm}$ ). The fraction $<0.063 \mathrm{~mm}$ was used for As and $\mathrm{Hg}$ determinations for all experimental work.

All reagents used were of analytical grade (Merck, Darmstadt, Germany). All solutions and dilutions were prepared using Milli-Q water (18.2 $\mathrm{M} \Omega \mathrm{cm}^{-1}$, Millipore Direct-Q 3, France). The calibration curves were prepared by adequate dilution of $1000 \mathrm{mg} \mathrm{L}^{-1}$ reference solutions (Merck, Darmstadt, Germany).

\section{Apparatus}

Arsenic and mercury determinations were performed by a Perkin-Elmer AAnalyst FIAS 100 (Shelton, USA) hydride generator system coupled with a Perkin-Elmer AAnalyst 
Table 2. Instrumental conditions of the HG AAS FIAS 100

\begin{tabular}{|c|c|c|}
\hline Parameters & As & $\mathrm{Hg}$ \\
\hline Wavelength / nm & 193.70 & 253.65 \\
\hline Flame composition & Air-Acetylene & - \\
\hline Current / mA & 400 & 180 \\
\hline Reductant - Flow & $\mathrm{NaBH}_{4}=4-6 \mathrm{~mL} \mathrm{~min}-1$ & $\mathrm{NaBH}_{4}=4-6 \mathrm{~mL} \mathrm{~min}{ }^{-1}$ \\
\hline Carrier Acid - Flow & $\mathrm{HCl}=8-12 \mathrm{~mL} \mathrm{~min}{ }^{-1}$ & $\mathrm{HCl}=8-12 \mathrm{~mL} \mathrm{~min}{ }^{-1}$ \\
\hline Carrier Gas - Flow & $\operatorname{Argon}=50 \mathrm{~mL} \mathrm{~min}{ }^{-1}$ & Argon $=50 \mathrm{~mL} \mathrm{~min}^{-1}$ \\
\hline Linear Calibration range / $\left(\mu \mathrm{g} \mathrm{L}^{-1}\right)$ & $0-200$ & $0-300$ \\
\hline$\underline{\text { Background Correction }}$ & Deuterium Lamp & - \\
\hline
\end{tabular}

200 (Shelton, USA) flame atomic absorption spectrometer (Shelton, USA). The instrumental conditions are described in Table 2. For Hg speciation, a thermodesorption system coupled to atomic absorption spectrometer Analitica GBC 932 AA (São Paulo, Brasil) with a deuterium lamp as background corrector was used. Direct mercury analyzer (DMA) instrument by Milestone DMA-80 TRI-CELL (Sorisole, Italy) was used to determine $\mathrm{Hg}$ in a solid sample.

Elemental characterization was done using CHNS 2400 Perkin Elmer (PE 2400 Series II CHNS/O Analyzer) (Shelton, USA).

\section{Sample pretreatment procedures}

\section{Pseudo-total digestion procedure}

It was used aqua regia as the extractor for the pseudototal digestion based on previous works. ${ }^{22,23}$ Therefore, $10 \mathrm{~mL}$ of recently prepared aqua regia were added to about $1000 \mathrm{mg}$ of sediment (fraction $<0.063 \mathrm{~mm}$ ). The mixture was kept for $16 \mathrm{~h}$ at room temperature, then refluxed for $2 \mathrm{~h}$ in a digestion block at $90^{\circ} \mathrm{C}$. Next, the volume was increased to $40.0 \mathrm{~mL}$ using Milli-Q water. The sample was then centrifuged for $20 \mathrm{~min}$ at $3000 \mathrm{rpm}$ and the supernadant analysed by HG AAS. Standard reference materials (SRM 1944 New Jersey - Waterway Sediment, and NIST SRM 2711 Montana Soil) received the same sample pretreatment. The procedure was performed three times for samples and certified reference materials.

\section{Partial extraction procedure}

About $500 \mathrm{mg}$ of sediment was directly and accurately weighted in a $50.0 \mathrm{~mL}$ centrifuge tube. Then $20 \mathrm{~mL}$ of $1.0 \mathrm{~mol} \mathrm{~L}^{-1} \mathrm{HCl}$ solution was added. The mixture was submitted to an ultrasound bath for $1 \mathrm{~h}$. Next, the mixture was centrifuged, and the supernadant was analysed by HG AAS.

\section{Direct mercury analysis (DMA)}

About $100 \mathrm{mg}$ of sediment was directly and accurately weighted in quartz boats. Then, samples were submitted to a heating program (drying $80 \mathrm{~s}$ at $200{ }^{\circ} \mathrm{C}$, thermal decomposition at $650{ }^{\circ} \mathrm{C}$ for $180 \mathrm{~s}$, following to $100 \mathrm{~s}$ for analytical signal and cooling). An amalgamator selectively traps $\mathrm{Hg}$ and an oxygen stream remove any remaining gases or decomposition products (60 s); the amalgamator is rapidly heated (12 s), releasing $\mathrm{Hg}$ vapor. Atomic absorbance is measured at $253.7 \mathrm{~nm}$. The instrument was calibrated in the range of 0 to $20 \mathrm{ng}$ absolute of $\mathrm{Hg}$. To check accuracy, two reference materials NIST-2711 (Montana Soil) and IAEA-336 (Trace Elements in Lichens) with $\mathrm{Hg}$ concentrations of $6.25 \pm 0.19 \mu \mathrm{g} \mathrm{g}^{-1}$ and $200 \pm 40 \mathrm{ng} \mathrm{g}^{-1}$, respectively were used. The limit of detection (LOD) was calculated by three times the average of the standard deviation of ten blanks and the slope of analytical curve. For the limit of quantification (LOQ), the same average was multiplied by 10 .

\section{Mercury speciation by TDAAS}

Sediment samples with the highest mercury contents (PTE 023 point) were submitted to the TDAAS analysis to identify the $\mathrm{Hg}$ species, as previously described by Durão Jr. et al. ${ }^{24}$ The system consists of an electronically controlled heating unit and one $\mathrm{Hg}$ detection unit. For $\mathrm{Hg}$ detection, a quartz tube through which the thermally released mercury is purged was placed in the optical system of an atomic absorption spectrometer. Detection was performed at $253.7 \mathrm{~nm}$. Analyses were carried out twice at a heating rate of $33{ }^{\circ} \mathrm{C} \mathrm{min}{ }^{-1}$ under a nitrogen

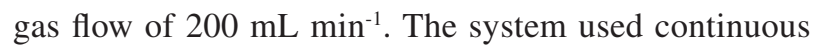
deuterium background correction to reduce interferences. Sample weight was about 400-2000 mg, depending on the total mercury content previously determined by HG AAS. Results from this system are registered as thermodesorption curves called thermograms, which show the release of mercury vs. temperature. The principle of the technique is that different species are released thermally at different temperatures. Thermograms of the samples were compared to thermograms of mercury standard substances $\left(\mathrm{Hg}(0), \mathrm{Hg}_{2} \mathrm{Cl}_{2}, \mathrm{HgCl}_{2}\right.$ and $\mathrm{HgO}$ ). 


\section{Data statistical analysis}

Data was analyzed using MINITAB, Version 14, for linear correlation (Pearson correlation) among the variables showed in Table 3. Multivariate analysis through hierarchical cluster analysis (HCA) also was performed to classify the samples according to the values of the studied variables into clusters and generate dendogram. Ward linkage method and Euclidean distance were used. The data was previously mean centered and autoscaled to Variance 1, to ensure that all variables contributed equally to the model, independent of the scale which they were measured.

\section{Results and Discussion}

Organic matter content was determined by elemental analysis CHN. Arsenic and mercury contents after aqua regia, partial extraction, and DMA procedures are presented in Table 3.
As previously said, all experimental work was developed with fraction $<0.063 \mathrm{~mm}$, but after sieving the samples, several of them presented predominantly fraction 0.063-2.0 mm, characterized as sandy. ${ }^{25}$

Organic matter contents shown in Table 3 ranged from 0.6 to $4.3 \%$. The presence of organic matter is responsible for the capability of interactions with other components and for changing the physical, chemical, and biological properties of soils and sediments. Furthermore, organic matter can cause the immobilization or the release of toxic elements to the plants, influencing the mobility, availability, volatility, and biodegradability of organic and inorganic molecules. ${ }^{26}$

\section{As and $\mathrm{Hg}$ contents in sediment samples}

Aqua regia pseudo-total digestion procedure

The limits of detection and quantification for As were $0.09 \mu \mathrm{g} \mathrm{g}^{-1}$ and $0.30 \mu \mathrm{g} \mathrm{g}{ }^{-1}$, and for $\mathrm{Hg}$ were $0.02 \mu \mathrm{g} \mathrm{g}^{-1}$ and

Table 3. Arsenic, mercury and organic matter contents in the sediment samples from São Francisco basin $(n=3)$

\begin{tabular}{|c|c|c|c|c|c|c|}
\hline \multirow{2}{*}{$\begin{array}{l}\text { Sampling } \\
\text { Point }\end{array}$} & \multirow[t]{2}{*}{$\mathrm{OM} /(\%)$} & \multicolumn{2}{|c|}{ As / $\left(\mu g g^{-1}\right)$} & \multicolumn{3}{|c|}{$\mathrm{Hg} /\left(\mu \mathrm{g} \mathrm{g}^{-1}\right)$} \\
\hline & & Aqua Regia & $\mathrm{HCl} 1.0 \mathrm{~mol} \mathrm{~L}^{-1}$ & Aqua Regia & DMA & $\mathrm{HCl} 1.0 \mathrm{~mol} \mathrm{~L}^{-1}$ \\
\hline ВР029 & 1.1 & $3.16 \pm 0.04$ & $2.16 \pm 0.17$ & $<$ LOD & $0.051 \pm 0.001$ & $<$ LOD \\
\hline BP036 & 2.0 & $7.61 \pm 0.19$ & $4.77 \pm 0.18$ & $<\mathrm{LOD}$ & $0.053 \pm 0.002$ & $0.044 \pm 0.005$ \\
\hline BP068 & 4.3 & $2.92 \pm 0.24$ & $1.96 \pm 0.11$ & $<\mathrm{LOD}$ & $0.067 \pm 0.005$ & $<\mathrm{LOD}$ \\
\hline BP070 & 2.7 & $2.64 \pm 0.08$ & $<$ LOD & $0.050 \pm 0.003$ & $0.114 \pm 0.003$ & $0.054 \pm 0.008$ \\
\hline BP079 & 2.1 & $7.86 \pm 0.58$ & $6.84 \pm 0.14$ & $0.050 \pm 0.010$ & $0.065 \pm 0.001$ & $0.057 \pm 0.005$ \\
\hline BP084 & 2.4 & $14.9 \pm 0.5$ & $13.0 \pm 0.4$ & $0.050 \pm 0.006$ & $0.114 \pm 0.002$ & $0.072 \pm 0.006$ \\
\hline BP086 & 3.5 & $3.27 \pm 0.17$ & $<\mathrm{LOD}$ & $0.25 \pm 0.008$ & $0.329 \pm 0.013$ & $0.20 \pm 0.01$ \\
\hline BV142 & 1.2 & $102 \pm 3$ & $31.3 \pm 2.1$ & $<\mathrm{LOD}$ & $0.069 \pm 0.004$ & $<\mathrm{LOD}$ \\
\hline BV149 & 1.2 & $53.9 \pm 1.9$ & $9.73 \pm 0.60$ & $0.047 \pm 0.003$ & $0.058 \pm 0.001$ & $0.045 \pm 0.006$ \\
\hline BV156 & 2.1 & $82.9 \pm 0.9$ & $14.2 \pm 0.9$ & $<\mathrm{LOD}$ & $0.122 \pm 0.006$ & $0.023 \pm 0.004$ \\
\hline РT007 & 2.0 & $2.15 \pm 0.02$ & $1.07 \pm 0.07$ & $0.11 \pm 0.01$ & $0.084 \pm 0.003$ & $<\mathrm{LOD}$ \\
\hline PTE003 & 2.4 & $4.87 \pm 0.20$ & $<\mathrm{LOD}$ & $0.054 \pm 0.006$ & $0.086 \pm 0.001$ & $0.053 \pm 0.008$ \\
\hline PTE005 & 2.7 & $3.90 \pm 0.32$ & $<\mathrm{LOD}$ & $0.030 \pm 0.002$ & $0.164 \pm 0.007$ & $0.034 \pm 0.002$ \\
\hline PTE007 & 1.4 & $4.28 \pm 0.17$ & $<\mathrm{LOD}$ & $<\mathrm{LOD}$ & $0.063 \pm 0.002$ & $<\mathrm{LOD}$ \\
\hline PTE013 & 1.4 & $6.11 \pm 0.11$ & $2.28 \pm 0.13$ & $<\mathrm{LOD}$ & $0.052 \pm 0.001$ & $<\mathrm{LOD}$ \\
\hline PTE015 & 2.1 & $5.83 \pm 0.02$ & $2.69 \pm 0.22$ & $0.089 \pm 0.025$ & $0.069 \pm 0.001$ & $0.087 \pm 0.011$ \\
\hline PTE023 & 2.0 & $309 \pm 15$ & $59.8 \pm 1.0$ & $2.3 \pm 0.1$ & $2.04 \pm 0.06$ & $0.11 \pm 0.01$ \\
\hline PTE025 & 2.1 & $5.04 \pm 0.24$ & $2.85 \pm 0.11$ & $<\mathrm{LOD}$ & $0.036 \pm 0.001$ & $<\mathrm{LOD}$ \\
\hline PTE027 & 2.5 & $3.59 \pm 0.14$ & $2.04 \pm 0.19$ & $<\mathrm{LOD}$ & $0.077 \pm 0.001$ & $0.019 \pm 0.002$ \\
\hline PTE029 & 2.2 & $16.8 \pm 0.30$ & $6.58 \pm 0.58$ & $<\mathrm{LOD}$ & $0.059 \pm 0.001$ & $<\mathrm{LOD}$ \\
\hline PTE031 & 3.3 & $16.5 \pm 0.13$ & $9.85 \pm 0.75$ & $0.32 \pm 0.014$ & $0.207 \pm 0.007$ & $<\mathrm{LOD}$ \\
\hline PTE033 & 2.4 & $7.38 \pm 0.22$ & $6.62 \pm 0.38$ & $0.045 \pm 0.003$ & $0.153 \pm 0.001$ & $0.031 \pm 0.003$ \\
\hline SF015 & 2.0 & $3.13 \pm 0.06$ & $2.55 \pm 0.06$ & $0.082 \pm 0.003$ & $0.085 \pm 0.001$ & $0.015 \pm 0.002$ \\
\hline SF017 & 0.6 & $4.11 \pm 0.03$ & $<\mathrm{LOD}$ & $<\mathrm{LOD}$ & $0.063 \pm 0.001$ & $<\mathrm{LOD}$ \\
\hline SF019 & 2.2 & $1.86 \pm 0.07$ & $<\mathrm{LOD}$ & $0.18 \pm 0.01$ & $0.105 \pm 0.003$ & $0.118 \pm 0.004$ \\
\hline SF027 & 1.7 & $6.44 \pm 0.33$ & $3.71 \pm 0.28$ & $<\mathrm{LOD}$ & $0.072 \pm 0.003$ & $<\mathrm{LOD}$ \\
\hline SF033 & 3.2 & $6.40 \pm 0.50$ & $5.98 \pm 0.45$ & $0.036 \pm 0.001$ & $0.099 \pm 0.001$ & $0.029 \pm 0.003$ \\
\hline VG005 & 4.2 & $5.28 \pm 0.03$ & $4.02 \pm 0.31$ & $0.033 \pm 0.005$ & $0.154 \pm 0.005$ & $0.025 \pm 0.002$ \\
\hline
\end{tabular}

Aqua Regia [LOD $\left.\left(\mathrm{Hg}=0.02 \mu \mathrm{g} \mathrm{g}{ }^{-1}, \mathrm{As}=0.09 \mu \mathrm{g} \mathrm{g} \mathrm{g}^{-1}\right)\right] ; \mathrm{HCl} 1.0 \mathrm{~mol} \mathrm{~L}^{-1}\left[\mathrm{LOD}\left(\mathrm{Hg}=0.01 \mu \mathrm{g} \mathrm{g}{ }^{-1}, \mathrm{As}=0.06 \mu \mathrm{g} \mathrm{g}{ }^{-1}\right)\right] ; \mathrm{DMA}\left[\mathrm{LOD}\left(\mathrm{Hg}=0.005 \mu \mathrm{g} \mathrm{g}^{-1}\right)\right]$. 
$0.07 \mu \mathrm{g} \mathrm{g}^{-1}$, respectively. Results obtained after aqua regia pseudo-total procedure are showed in Table 3.

In Brazil, the 2004 CONAMA Resolution 344 established legal limits for some metals and organic compounds in sediments. This resolution is based on CCME (Canadian Council of Minister of the Environment) values. ${ }^{27,28}$ Level 1 from CONAMA corresponds to the TEL (Threshold Effects Level) index from CCME. Environmental damage is not expected to values below Level 1. The values between Level 1 and Level 2 indicate occasional adverse effects. Level 2 corresponds to the PEL (Probably Effects Level) index of CCME. Values above Level 2 frequently adversely affect the environment. ${ }^{29}$ Although such guidelines are not definitive indicators of toxicity, they have a high predictability, and the TEL/PEL-type guidelines offer scientific basis for comparability. ${ }^{29}$

For $\mathrm{Hg}$, four samples (BP 086, PTE 023, PTE 031 and SF 019) presented values above Level 1 for $\mathrm{Hg}$ at $0.17 \mu \mathrm{g} \mathrm{g}^{-1}$. For As, the Level 1 value is $5.9 \mu \mathrm{g} \mathrm{g}^{-1}$; thirteen samples (BP 036, BP 079, BP 084, BV 142, BV 149, BV 156, PTE 013, PTE 023, PTE 029, PTE 031, PTE 033, SF 027 and SF 033) surpassed this threshold.

Sample area PTE 023 was found to have the highest concentrations of both elements, above Level 2 from CONAMA (As $=17.0 \mu \mathrm{g} \mathrm{g}^{-1}, \mathrm{Hg}=0.486 \mu \mathrm{g} \mathrm{g}^{-1}$ ). In a subsequent sampling of PTE 023, the observed values that exceeded the limits level 2 for both As and $\mathrm{Hg}$ were $709 \pm 64 \mu \mathrm{g} \mathrm{g}^{-1}$ and $0.59 \pm 0.03 \mu \mathrm{g} \mathrm{g}^{-1}$, respectively. The area where this sample was taken is located in the Córrego Rico, where gold mining activities have occurred since the $18^{\text {th }}$ Century. This region has high arsenopyrite contents, FeAsS. ${ }^{30,31}$ Frequently, gold is found associated to this mineral, which explain high $\mathrm{As}$ and $\mathrm{Hg}$ levels in this place.

The samples from BP 036, BP 079, and BP 084 points presented As values between Level 1 and Level 2. Data in 2008 from IGAM (Instituto Mineiro de Gestão das Águas) on the water quality demonstrated that the main contamination sources in these areas (Paraopeba sub-basin) are related to domestic sewage and industrial effluents. $^{5}$

The IGAM report also emphasized that BV 142, BV 149, and BV 156 points, located in the Velhas River presents water contamination due to the release of domestic sewage from the Minas Gerais capital city and due to the released inorganic pollutant caused by mineral extraction. The Velhas River is the largest tributary, in extension, from the São Francisco River basin. Almost all urban sewage was thrown in the rivers without any treatment until 2001 when the first sewage treatment station was installed. Nowadays, $60 \%$ of urban sewage from the capital city is treated before being dumped into the rivers. ${ }^{5}$

The oldest gold mine active in the world, which began in 1834, is located in the Velhas River sub-basin; it is responsible for large residue deposits, mainly containing $\mathrm{As}_{2} \mathrm{O}_{3}{ }^{18}$ FEAM (Fundação Estadual do Meio Ambiente - The State Environment Foundation of Minas Gerais) data and IGAM reports show that mining activities have increased $\mathrm{As}$ and $\mathrm{Hg}$ concentrations in water at levels above the CONAMA limits in some areas of the Velhas River sub-basin. The samples from Baixo Velhas (BV 142, BV 149 and BV 156) presented high As content, related to gold mining in this region.

Deschamps and Matschullat ${ }^{18}$ accomplished As measurements in several matrices from the Iron Quadrangle between 1998 and 1999 and the contents found ranged from 50 to $3200 \mathrm{~g} \mathrm{~g} \mathrm{~g}^{-1}$ in the Velhas River sediments, near the oldest gold mine. In sediment samples from Paracatu, de Andrade et al. ${ }^{31}$ found arsenic concentrations up to $1500 \mu \mathrm{g} \mathrm{g}^{-1}$. Based on last report from IGAM, As and $\mathrm{Hg}$ in water were below the legal values.

Compared to those studies, the results obtained here show high concentrations in certain areas but suggest an overall reduction in $\mathrm{As}$ and $\mathrm{Hg}$ levels in sediments from the Minas Gerais state.

Results obtained for the certified reference materials after pseudo-total digestion procedure are showed in Table 4 . The results agreed with the certified reference values at the $95 \%$ confidence level for $\mathrm{Hg}$ and at the $99 \%$ confidence level for As (only NIST 2711) applying the t-Student test. For SRM 1944, arsenic concentration measurements were in the confidence interval, but precision was affected.

High $\mathrm{Hg}$ levels were determined for samples from PTE 023 and two other samplings were made in this area. These samples were submitted to a pseudo-total digestion procedure in the finest granulometric fraction $(<0.063 \mathrm{~mm})$. The analyses confirmed previous results

Table 4. Results for arsenic and mercury in standard reference materials after aqua regia pseudo-total digestion procedure

\begin{tabular}{lcccc}
\hline & \multicolumn{2}{c}{ NIST 1944 (New Jersey Waterway Sediment) } & \multicolumn{2}{c}{ NIST 2711 (Montana Soil) } \\
& Certified value & Obtained value & Certified value & Obtained value \\
\hline $\mathrm{As} /\left(\mu \mathrm{g} \mathrm{g}^{-1}\right)$ & $18.9 \pm 2.8$ & $16 \pm 0.1$ & $105 \pm 8$ & $89 \pm 3$ \\
$\mathrm{Hg} /\left(\mu \mathrm{g} \mathrm{g}^{-1}\right)$ & $3.4 \pm 0.5$ & $3.4 \pm 0.5$ & $6.25 \pm 0.19$ & $6.47 \pm 0.40$ \\
\hline
\end{tabular}


where $\mathrm{Hg}$ levels were above those established by CONAMA, as seen in Table 5. Mercury concentrations in PTE 023 samples were between $0.16 \mu \mathrm{g} \mathrm{g}^{-1}$ and $2.3 \mu \mathrm{g} \mathrm{g}^{-1}$. The results of the sample profile showed highest values in the superficial layer, indicating recent contamination and an irrelevant vertical migration.

Table 5. Mercury contents in the sediment samples from PTE 023 point after HG AAS determination

\begin{tabular}{lcc}
\hline Sediment samples & \multicolumn{2}{c}{$\mathrm{Hg} /\left(\mu \mathrm{g} \mathrm{g}^{-1}\right)$} \\
\cline { 2 - 3 } & HG AAS & DMA \\
\hline PTE023 09/06/2007 superficial & $2.30 \pm 0.10$ & $2.04 \pm 0.06$ \\
PTE023 03/06/2008 superficial & $0.59 \pm 0.03$ & $0.43 \pm 0.01$ \\
PTE023 08/28/2008 superficial & $0.49 \pm 0.02$ & $1.21 \pm 0.08$ \\
PTE023 08/28/2008 $(0-30 \mathrm{~cm})$ & $0.61 \pm 0.01$ & $0.55 \pm 0.04$ \\
PTE023 08/28/2008 $(30-60 \mathrm{~cm})$ & $0.25 \pm 0.04$ & $0.18 \pm 0.03$ \\
PTE023 08/28/2008 $(60-90 \mathrm{~cm})$ & $0.16 \pm 0.01$ & $0.19 \pm 0.01$ \\
\hline
\end{tabular}

\section{Partial extraction procedure}

The limits of detection and quantification for As were $0.06 \mu \mathrm{g} \mathrm{g}^{-1}$ and $0.19 \mu \mathrm{g} \mathrm{g}^{-1}$, and for $\mathrm{Hg}$ were $0.01 \mu \mathrm{g} \mathrm{g}^{-1}$ and $0.04 \mu \mathrm{g} \mathrm{g}^{-1}$, respectively. Results are showed in Table 3 . The $\mathrm{Hg}$ contents obtained in the partial extraction were close to the pseudo-total values for almost all samples, except for PTE 023 and SF 015. The As percent composition after the partial extraction procedure ranged from $17 \%$ to $93 \%$, compared to the pseudo-digestion. The samples that exceeded the CONAMA Level 2 presented extraction values lower than $40 \%$. It should be noted that high values from pseudo-digestion were related to low values after partial extraction procedure, indicating the low mobility and availability for As in these points.

Minas Gerais soil contains abundant levels of iron oxides and hydroxides, which are known for their high adsorbitivity. Recent data show that As mobility is reduced by high iron concentration. ${ }^{32-34}$ Therefore, it can be presumed that the highest As concentrations obtained correspond to low mobility due to the iron oxide concentration in the soil.

Mercury forms less labile compounds with iron oxides and mainly with sulfur. $\mathrm{Hg}$ and sulfur are soft ligands and can form inner-sphere compounds. So, $\mathrm{Hg}$ often forms stable complexes with humic substances. ${ }^{10}$ Some studies report the importance of sulfides in the control of releasing metals from sediments into the aquatic system. In general, an increase in sulfides reduces a metal's bioavailability to water flow. ${ }^{35}$ The samples from PTE 023, which presented the highest $\mathrm{As}$ and $\mathrm{Hg}$ levels, are located in a region of naturally occuring high sulfides levels. ${ }^{30,31}$
Samples with low percentages in the partial extraction procedure might be due to partial imobilization of As and $\mathrm{Hg}$ from the iron oxides and sulfides present in the sediments.

Data from Table 3 was submitted to a Pearson correlation test $(\mathrm{P}<0.05$ and $\mathrm{N}=28)$. The test showed a positive and significant correlation for $\mathrm{Hg}$ and $\mathrm{As}(\mathrm{r}=0.62)$. This correlation can be explained by occurrence of arsenopyrite, associated with gold. The correlations between the pseudo-total digestion and $1.0 \mathrm{~mol} \mathrm{~L}^{-1} \mathrm{HCl}$ extraction procedures were also significant, indicating that the diluted acid extraction is efficient for As and $\mathrm{Hg}$ in some cases.

Figure 2 illustrates the dendogram obtained after aqua regia and partial extraction procedures for the samples. With this analyses, a group of samples is formed and linked through similarities. Three groups were observed. The BV's samples formed one group due to elevated As levels and low mobility. The other groups were formed by samples with contents below Level 2 and by samples that presented high availability to water flow.

Dendogram with Ward's method and Euclidian distances

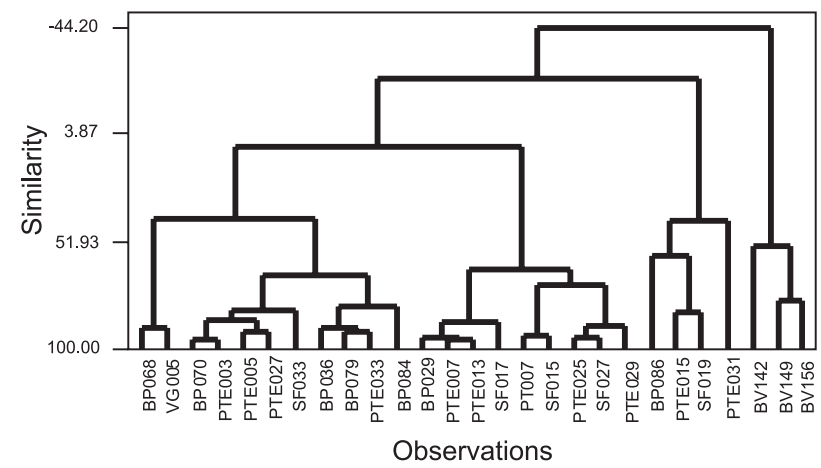

Figure 2. Dendogram of sediment samples after aqua regia and partial extraction procedures.

\section{Direct mercury analysis (DMA)}

The DMA instrument uses thermal decomposition for $\mathrm{Hg}$ determination. Limits of detection and quantification for $\mathrm{Hg}$ were 0.005 and $0.0165 \mu \mathrm{g} \mathrm{g}^{-1}$, respectively. The results of the reference materials were: NIST 2711 (Montana Soil), certified value $6.25 \pm 0.19 \mu \mathrm{g} \mathrm{g}^{-1}$, obtained value $6.51 \pm 0.05 \mu \mathrm{g} \mathrm{g}^{-1}$; IAEA336 (Trace Elements in Lichens), certified value $200 \pm 40 \mathrm{ng} \mathrm{g}^{-1}$, obtained value $210 \pm 6 \mathrm{ng} \mathrm{g}^{-1}$.

The maximum $\mathrm{Hg}$ concentration was found in the sample PTE 023, in accordance with wet procedures. All results presented in Table 3 showed good agreement with those obtained after wet sample pretreatment procedures. Solid sampling is advantageous due to minor sample handling and low risks of contamination. 


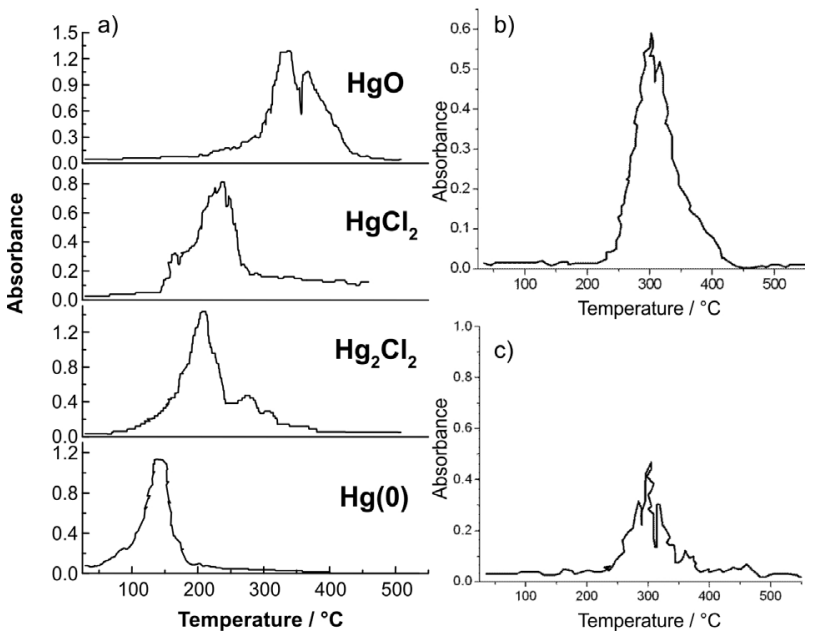

Figure 3. Mercury thermograms: (a) thermograms of standard samples of $\mathrm{Hg}$ compounds (adapted from reference 35); (b) and (c) thermograms of superficial sediments samples from PTE 023 point.

\section{Mercury speciation}

Chemical species determination is relevant to bioavailability processes. The PTE 023 sediment samples were submitted to TDAAS and the results are shown in Figure 3.

Figure 3 a shows thermograms obtained from Valle et al. ${ }^{35}$ in simulated samples containing different $\mathrm{Hg}$ species, using the same equipment and under the same conditions used in this work. The $\operatorname{Hg}(0)$ begins to be released between room temperature up to $200{ }^{\circ} \mathrm{C}, \mathrm{Hg}(\mathrm{I})$ is released at $100{ }^{\circ} \mathrm{C}$ up to $250{ }^{\circ} \mathrm{C}$, and $\mathrm{Hg}$ (II) is released at temperatures above $200{ }^{\circ} \mathrm{C}$ until approximately $350{ }^{\circ} \mathrm{C}$. The $\mathrm{Hg}$ bound to humic substances presents peaks at higher temperatures, above $400{ }^{\circ} \mathrm{C}$. At $600^{\circ} \mathrm{C}$, all of the $\mathrm{Hg}$ species had been completely released. Thus, it is possible to make a qualitative study of the $\mathrm{Hg}$ species in solid samples using TDAAS. Representative thermograms obtained to the PTE 023 samples are presented in the Figures $3 \mathrm{~b}$ and $3 \mathrm{c}$.

In PTE 023 point, four samples were collected in three different periods. One of them was collected in three different depths $(0-30 \mathrm{~cm}, 3-60 \mathrm{~cm}, 6-90 \mathrm{~cm})$. Ten thermograms were done, four of them "in natura" samples and the others dried samples. Only one peak was observed for all of them, indicating that only one species was found. In all the thermograms, this peak occurs at the same temperature range, between $200^{\circ} \mathrm{C}$ and $400{ }^{\circ} \mathrm{C}$. Therefore, the $\mathrm{Hg}$ species present in all of the samples is $\mathrm{Hg}$ (II).

Over the last three centuries, the area PTE 023 was a gold prospecting area, in which $\mathrm{Hg}(0)$ was used to improve the gold extraction efficiency. However, the thermograms presented peaks related to the $\mathrm{Hg}$ (II) contamination, indicating that $\mathrm{Hg}$ suffered a natural oxidation process over the years. ${ }^{35}$ After oxidation, $\mathrm{Hg}$ (II) can be adsorbed into clay minerals, complexed with organic matter, or transfered to the water flow.

\section{Conclusions}

The aqua regia pseudo-total digestion procedure was a simple and adequate strategy for sediment sample preparation. Results presented high precision and accuracy. The obtained results proved that some areas of the São Francisco Basin are degraded by anthropogenic activities. Thirteen samples demonstrated As levels above CONAMA Level 1, and four samples exceeded the CONAMA Level 2. Three samples exceeded the Level $1 \mathrm{Hg}$ values, and one sample was higher than Level 2. Compared to the earliest research in this region, it is reasonable to conclude that contamination levels have been reduced, probably due to monitoring and inspection activities.

The partial extraction procedure produced results in agreement with those from aqua regia pseudo-total digestion for almost all samples. The partial extraction procedure was simple and fast, giving information about mobility and availability of toxic elements using diluted acid solutions as natural conditions. Therefore, samples with elevated $\mathrm{As}$ and $\mathrm{Hg}$ levels had low mobility into water flow. Results for $\mathrm{Hg}$ determination in the samples submitted to wet pretreatment procedures showed good agreement with solid sampling using DMA.

The results obtained by TDAAS showed that only $\mathrm{Hg}$ (II) is present in the sediment samples. $\mathrm{Hg}(0)$ used in the gold prospection can be partially oxidize to $\mathrm{Hg}$ (II) in the environmental conditions, and this fact requires further attention once $\mathrm{Hg}(\mathrm{II})$ can be methylated and form more toxic species.

\section{Supplementary Information}

Supplementary data are available free of charge at http://jbcs.sbq.org.br as PDF file.

\section{Acknowledgments}

L. M. C., C. C. N. and C. C. W. would like to thank the Conselho Nacional de Desenvolvimento Científico e Tecnológico (CNPq) and Fundação de Amparo à Pesquisa do Estado de Minas Gerais (FAPEMIG-ECT479/07) for their financial support. P. S. R. acknowledges the fellowships provided by FAPEMIG, P. A. S. M. and W. A. D. Jr. acknowledge the fellowships provided by CNPq. Authors are also thankful to CETEC and IGAM for sample collections. 


\section{References}

1. Atkinson, C. A.; Jolle, D. F.; Simpson, S. L.; Chemosphere 2007, 69, 1428.

2. Altug, G.; Balkis, N.; Env. Monit. Ass. 2009, 149, 61.

3. www.ana.gov.br accessed in January 2009.

4. www.ibge.gov.br accessed in January 2009.

5. www.igam.mg.gov.br accessed in March 2009.

6. Salomons, W.; Stigliani, W.; Biogeodynamics of Pollutants in Soils and Sediments: Risk Assessment of Ddelayed and NonLinear Responses, Springer-Verlag: Heidelberg, 1995.

7. Duffus, J. H.; Toxicologia Ambiental, Ediciones Omega: Barcelona, 1983.

8. Windmöller, C. C.; Santos, R. C.; Athayde, M.; Palmieri, H. E. L.; Quim. Nova 2007, 30, 1088.

9. Micaroni, R. C. C. M.; Bueno, M. I. M. S.; Jardim, W. F.; Quim. Nova 2000, 23, 487.

10. Issaro, N.; Abi-Ghanem, C.; Bermond, A.; Anal. Chim. Acta 2009, 631, 1 .

11. Furutani, A.; Rudd, J. W. M.; Appl. Environ. Microbiol. 1980, 40,770 .

12. Murphy, J.; Jones, P.; Hill, S. J.; Spectrochim. Acta, Part B 1996, $51,1867$.

13. Paraqueti, H. H. M.; Ayres, G. A.; Almeida, M. D.; Molisani, M. M.; Lacerda, L. D.; Water Res. 2004, 38, 1439.

14. Bisinoti, M. C.; Sargentini Jr, E.; Jardim, W. F.; J. Braz. Chem. Soc. 2007, 18, 544.

15. http://www.worldfish.org/PPA/PDFs/Semi-Annual\%20VII/E$6 \mathrm{~b} \% 20$ UFSCar\%20Metals\%20Project\%20Technical\%20 Report-\%20port.pdf acessed in March 2009.

16. http://www.mma.gov.br/conama/ acessed in January 2009.

17. Alloway, B. J.; Heavy Metals in Soils, John Wiley \& Sons: New York, 1990.

18. Deschamps, E.; Matschullat, J.; Arsênio Antropogênico e Natural: Um Estudo em Regiões do Quadrilátero Ferrífero, FEAM: Belo Horizonte, Brasil, 2007. ISBN 978-85-61029-00-5

19. Maher, W. A.; Anal. Chim. Acta 1981, 126, 157.

20. Borba, R. P.; Figueiredo, B. R.; Rawlins, B.; Matschullat, J.; Rev. Bras. Geoc. 2000, 30, 558.

21. Deschamps, E.; Ciminelli, V. S. T.; Lange, F. T.; Matschullat, J.; Raue, B.; Schmidt, H.; J. Soils Sediments 2002, 2, 216.

22. Larner, B. L; Seen, A. J.; Townsend, A. T.; Anal. Chim. Acta 2006, 556, 444.
23. Larner, B. L; Palmer, A. S.; Seen, A. J.; Townsend, A. T.; Anal. Chim. Acta 2008, 608, 147.

24. Durão Jr., W. A.; Palmieri, H. E. L.; Trindade, M. C.; Branco, O. E. A.; Carvalho F ${ }^{\circ}$, C. A.; Fleming, P. M.; Silva, J. B. B.; Windmöller, C. C.; J. Environ. Monit. 2009, 11, 1056.

25. EMBRAPA, Empresa Brasileira de Pesquisa Agropecuária; Manual de Métodos de Análise de Solo, 2a. ed., EMBRAPA, Centro Nacional de Pesquisa de Solos: Rio de Janeiro, Brasil, 1997. ISBN 85-8586403-6.

26. Meurer, E. J.; Fundamentos de Química do Solo, 3a. ed., UFRGS: Porto Alegre, Brasil, 2008.

27. Canadian Council of Ministers of the Environment; Canadian Sediment Quality Guidelines for the Protection of Aquatic Life: Arsenic, In Canadian Environmental Quality Guidelines; Canadian Council of Ministers of the Environment: Winnipeg, 1999. http://ceqg-rcqe.ccme.ca/download/en/230/ accessed in January 2009.

28. Canadian Council of Ministers of the Environment; Canadian Sediment Quality Guidelines for the Protection of Aquatic Life: Mercury, In Canadian Environmental Quality Guidelines; Canadian Council of Ministers of the Environment: Winnipeg, 1999. http://ceqg-rcqe.ccme.ca/download/en/241/ accessed in January 2009.

29. Hubner, R.; Astin, K. B.; Herbert, R. J. H.; J. Environ. Monit. 2009, 11, 713.

30. de Andrade, R. P.; Santana F ${ }^{\circ}$, S.; Mello, J. W. V.; Figueiredo, B. R.; Dussin, T. M.; Quim. Nova 2008, 31, 1127.

31. de Andrade, R. P.; Figueiredo, B. R.; Mello, J. W. V.; Santos, J. C. Z.; Zandonadi, L. U.; J. Soils Sediments 2008, 8, 123.

32. Deschamps, E.; Ciminelli, V. S. T.; Weidler, P. G.; Ramos, A. Y.; Clays Clay Miner. 2003, 51, 197.

33. Mello, J. W. V.; Talbott, J. L.; Scott, J.; Roy, W. R.; Stucki, J. W.; Environ. Sci. Pollut. Res. 2007, 14, 388.

34. Yu, K. C.; Tsai, L. J.; Chen, S. H.; Ho, S. T.; Water Res. 2001, 35,4086

35. Valle, C. M.; Santana, G. P.; Windmöller, C. C.; Chemosphere 2006, 65, 1966.

Submitted: April 17, 2010

Published online: February 3, 2011 


\section{Arsenic and Mercury Mobility in Brazilian Sediments from São Francisco River Basin}

Patrícia S. Rezende, Priscila A. S. Moura, Walter A. Durão Jr., Clésia C. Nascentes, Cláudia C. Windmöller and Letícia M. Costa*

Departamento de Química, ICEx, Universidade Federal de Minas Gerais,

Avenida Presidente Antônio Carlos, 6627, Pampulha, 31270-901 Belo Horizonte-MG, Brazil

\section{Dendogram with Ward's method and Euclidian distances}

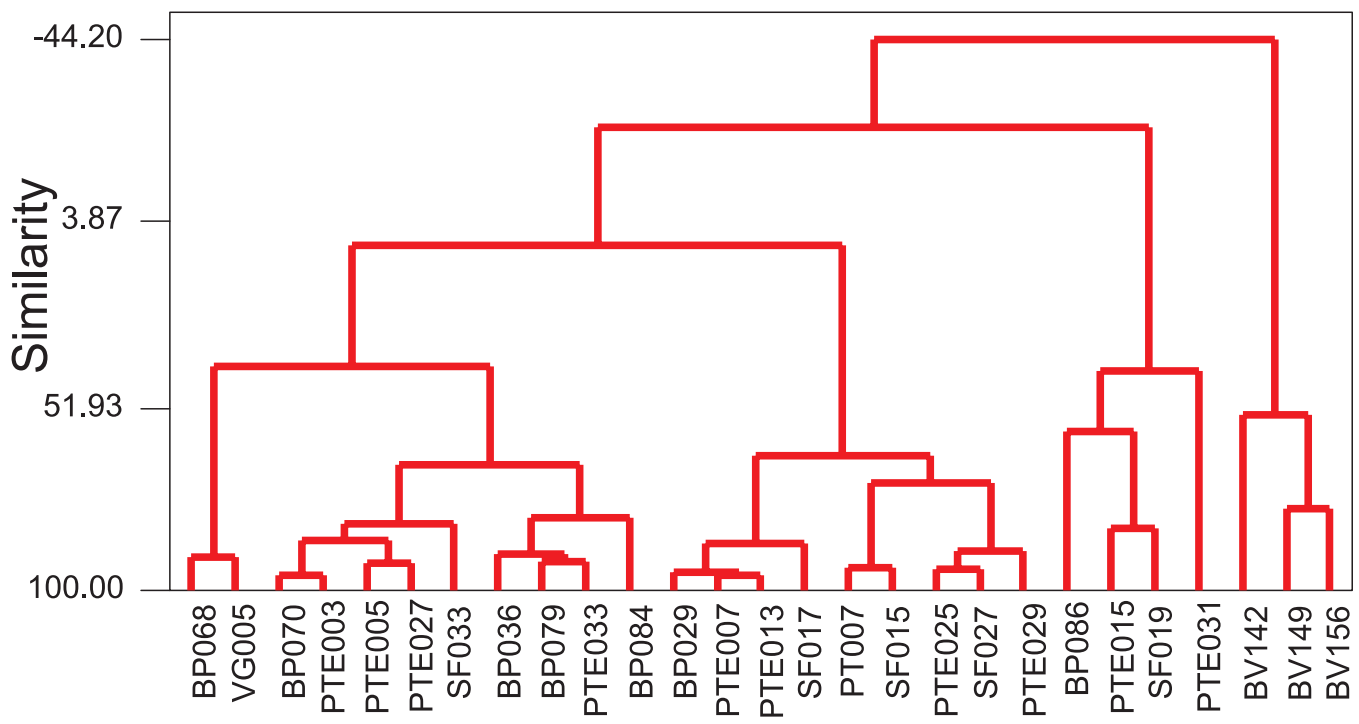

Observations

Figure S1. Dendogram of sediment samples after aqua regia and partial extraction procedures. 